IZA DP No. 7504

Perception of Workplace Discrimination among Immigrants and Native Born New Zealanders

Bridget Daldy

Jacques Poot

Matthew Roskruge

July 2013 


\title{
Perception of Workplace Discrimination among Immigrants and Native Born New Zealanders
}

\author{
Bridget Daldy \\ University of Waikato \\ Jacques Poot \\ University of Waikato and IZA \\ Matthew Roskruge \\ University of Waikato
Discussion Paper No. 7504
July 2013 \\ IZA
P.O. Box 7240
53072 Bonn
Germany \\ Phone: +49-228-3894-0 \\ Fax: +49-228-3894-180 \\ E-mail: iza@iza.org
}

\begin{abstract}
Any opinions expressed here are those of the author(s) and not those of IZA. Research published in this series may include views on policy, but the institute itself takes no institutional policy positions. The IZA research network is committed to the IZA Guiding Principles of Research Integrity.

The Institute for the Study of Labor (IZA) in Bonn is a local and virtual international research center and a place of communication between science, politics and business. IZA is an independent nonprofit organization supported by Deutsche Post Foundation. The center is associated with the University of Bonn and offers a stimulating research environment through its international network, workshops and conferences, data service, project support, research visits and doctoral program. IZA engages in (i) original and internationally competitive research in all fields of labor economics, (ii) development of policy concepts, and (iii) dissemination of research results and concepts to the interested public.
\end{abstract}

IZA Discussion Papers often represent preliminary work and are circulated to encourage discussion. Citation of such a paper should account for its provisional character. A revised version may be available directly from the author. 


\section{ABSTRACT \\ Perception of Workplace Discrimination among
Immigrants and Native Born New Zealanders}

Despite considerable research on differences in labour market outcomes between native born New Zealanders and immigrants, the extent of discrimination experienced by the foreign born in the workplace remains relatively unexplored. We use micro data from the Confidentialised Unit Record File of the 2008 New Zealand General Social Survey ( $\mathrm{n}=$ 8,721 ) to examine the determinants of self-reported discrimination in the workplace. We find that immigrants are significantly more likely than New Zealand-born employees to report that they experience discrimination in the workplace. There are noticeable gender differences in determinants of perceived discrimination, which interact with birthplace. The highest likelihood of self-reported workplace discrimination is found amongst migrants from Asia and the Pacific Islands. Discrimination is more likely to be reported by those with higher education and those who are mid-career. We test and correct for selection bias in measuring the impact of factors influencing perceived discrimination and find such bias to be present for men but not for women.

JEL Classification: $\quad$ F22, J01, J71

Keywords: immigration, workplace discrimination, New Zealand, sample selection bias

Corresponding author:

Jacques Poot

National Institute of Demographic and Economic Analysis (NIDEA)

University of Waikato

Private Bag 3105

Hamilton, 3240

New Zealand

E-mail: jpoot@waikato.ac.nz

\footnotetext{
* This paper has been published in a special issue of the Australian Journal of Labour Economics on labour market discrimination (Volume 16, Number 1, 2013). The research for the paper was funded by the Foundation for Research Science and Technology as part of the 2007-2012 Integration of Immigrants Programme (grant MAUX0605). We wish to thank Marietjie van Dyk for her excellent research assistance and two anonymous referees for their helpful comments. Access to the data used in this study was provided by Statistics New Zealand under conditions designed to keep individual information secure in accordance with requirements of the Statistics Act 1975. The opinions presented in this paper are those of the authors and do not necessarily represent an official view of Statistics New Zealand.
} 


\section{Introduction}

This paper provides an empirical analysis of the extent of workplace discrimination perceived by migrants in New Zealand. International evidence suggests that as many as 40 per cent of all migrants may experience some form of discrimination in the workplace (Girling et al., 2010). A recent Australian review concludes that 'race-based' discrimination (linked to race, ethnicity, culture or religion) remains unacceptably high and may in fact be increasing (Trenerry et al. 2012). Such discrimination has significant social and economic costs. At the workplace, these costs include health problems and poorer performance, less trust and morale, but also increased absenteeism and staff turnover.

Legislation has been introduced in many countries, including New Zealand, to encourage employers to become more impartial in their recruitment processes and in dealing with existing migrant staff. Some interventions such as diversity training, modified recruitment practices and improving workplace culture can be effective (Trenerry et al. 2012) but much remains to be done to reduce migrant discrimination, as studies in New Zealand (Watts \& Trlin, 2000), Australia (Lewis et al., 2000), The Netherlands (Verbeek and Groeneveld, 2012) and internationally (Castles, 2000) suggest.

New Zealand has, like Australia, one of the world's highest shares of foreign born among the population. At the 2006 census 23 per cent of the population was born abroad and it is estimated that this percentage has increased further since then (to be confirmed by the 2013 census) with around 50-60,000 new immigrants arriving each year who have been effectively substituting for New Zealand born emigrants (Spoonley \& Bedford, 2012). Some studies have shown that New Zealanders have a generally positive attitude toward immigrants and endorse multiculturalism (Ward \& Masgoret, 2008; Ward et al., 2011). However, discrimination issues experienced in other countries are also common in New Zealand, especially for those migrant groups that are culturally (and often 'visibly') different from the 
majority European or indigenous Maori populations (Girling et al., 2010; Statistics New Zealand, 2012). Wilson \& Parker (2007) argue that particularly discrimination at work remains an issue for migrants and may require further policy responses in order to mitigate the harm it causes. Moreover, up to one quarter of immigrants subsequently leave the country again, with many of these having entered under the Skilled Migrant Category or as business migrants (Department of Labour, 2009). Workplace discrimination could be one of the reasons for return or onward migration.

This paper therefore aims to identify the key worker characteristics that are associated with higher or lower rates of perceived discrimination, with a focus on factors which influence migrants' perceptions and how these differ from other groups. We use microdata from the 2008 New Zealand General Social Survey (NZGSS). There has also been a second NZGSS in 2010, but at the time of writing of this paper, the data were not yet available publicly in Confidentialised Unit Record File (CURF) form.

A brief recent Statistics New Zealand (2012) report shows that in the combined 2008 and 2010 data one in ten people aged 15 or over experienced some form of discrimination over a 12 month period. The highest levels of discrimination occurred in employment settings. However, the limited evidence published to date has been purely descriptive. The present paper is the first to provide detailed econometric modelling with the NZGSS data.

We begin with a brief overview of previous research into migrant discrimination in New Zealand and internationally in section 2. This provides both a theoretical framework for model development and a narrative for the findings of the quantitative analysis. Section 3 introduces the NZGSS data and the methodologies that have been employed to estimate the factors which influence the experience of discrimination by migrants in the workplace. These consist of the standard probit model and the Heckman-probit model. The latter model tests for selection effects in employment that could potentially bias measurement of the impact of 
various worker characteristics that influence perceived discrimination. Section 4 provides the results of regression modelling. Conclusions and suggestions for further research are presented in section 5 .

\section{Previous Research}

Formally, perceived discrimination may be defined as the situation in which 'an individual feels that they have been treated unfairly because of their membership of a particular social category' (Banerjee, 2008, p.384). In addition to the discrimination which may be perceived and experienced by workers due to factors such as age and gender, migrants may encounter additional discrimination due to their cultural differences from native born individuals. Trenerry (2012, p6) suggests that 'systemic race-based discrimination in the workplace occurs through avoidable and unfair differences in recruitment, selection and interviewing, job allocation, seniority, role ambiguity, performance evaluation, training, promotion, remuneration, dismissal, resignations and retirement among staff of various racial, ethnic, cultural and religious backgrounds.'

Workplace discrimination studies have found that employers may discriminate against employees, or potential employees, in many different ways and for many different reasons (Trenerry, et al., 2012), for example leading to lower wages and higher unemployment (Lang and Lehmann, 2012). This can occur in both the public and the private sectors (Heywood, 1989; Groeneveld and Verbeek, 2012). Often discrimination within the workforce starts with recruitment, as can be seen from a field experiment conducted by Oreopoulos (2011) who found that significant discrimination occurred when people with non-English names applied for jobs in Canada, despite controlling for occupation and work experience in Canada or in another country (see Pager and Western, 2012, for similar U.S. experiments). However, it 
can also manifest itself in promotion processes and in day-to-day interaction with the employees.

Since the 1960s, workplace discrimination has been recognised as a big issue throughout the world and triggered equal employment opportunities legislation (e.g., Watson et al., 2009). New Zealand legislation included the Equal Pay Act of 1972, the Equal Employment and Pay Equity Act of 1990 and the Human Rights Acts 1993, which was updated in 2000. The aim of these laws is to create an impartial workplace and encourage workplace diversity. The laws encourage equal employment opportunities (EEO) practices and make available a range of resources to employers to help ensure that all employees are considered for the employment of their choice and have the chance to perform to their maximum potential. The Employment Relations Act and the Employment Amendment Act have also both contributed to reducing discrimination within the workforce, but their effectiveness has been limited, particularly with respect to migrants (Wilson \& Parker, 2007).

Economic theory suggests that a diverse workforce has many benefits to a business, including increased flexibility, adaptability, and positive workplace culture (e.g. Page, 2007; EEO Trust, 2008; Trenerry et al., 2012). Cultural diversity implies a greater choice of job candidates and can also improve customer service. Moreover, workers who believe that they are treated fairly are shown to be more productive and have higher rates of loyalty to their organisations (Trenerry et al., 2012). However, such economic benefits do not necessarily ensure equal employment opportunities. EEO Trust (2005) found that less than 50 percent of the businesses surveyed take action against biased recruitment and only a third of the organisations provide EEO training for their managers or require their employment consultants to attract a diverse range of clients for them to interview. 
Such business practices may contribute to differences in labour market outcomes across ethnic groups. Systematic differences in labour market outcomes, with visible minorities often having worse outcomes, are commonly observed, including in New Zealand (see Hodgson and Poot, 2010, for an extensive review). Moreover, wages of migrants who have jobs are often lower than those of comparable New Zealand born workers. Moreover, some migrants are employed in jobs for which they are overqualified, although this declines with length of stay in New Zealand (Poot and Stillman, 2010). While this may be due to e.g. non-transferability of skills (and wages do increase with increasing on -the-job experience in New Zealand), non-recognition of overseas qualifications may sometimes be discriminatory. There is also evidence to suggest that immigrants and ethnic minority groups are underrepresented or underpaid in many professions, and that immigrants with qualifications and experience applicable to high level jobs face biases in recruitment decisions (Wilson \& Parker, 2007).

There are many factors that influence the discrimination a person may have experienced and the degree of sensitivity towards such discrimination, and it may be that the perception of discrimination is just as damaging as the actual act of discrimination. Perceived discrimination within the workplace can lead to workers becoming less productive and having less job satisfaction. Perceived discrimination is subjective in the sense that it is only discrimination if the person who is being discriminated against believes the actions to be different from their established expectations and norms (Banerjee, 2008). There is evidence that perceived discrimination is under rather than over-reported (Kaiser and Major, 2006). Banerjee (2008) identified five variables that are crucial in influencing an immigrant's perception of discrimination.

The first of these is immigrant status. This can be measured in terms of the number of years the immigrant has resided in the host country or in terms of residency status (permanent 
resident or temporary visa holder). The evidence suggests that those who have only been in a country for a short length of time are more likely to feel discriminated against, particularly due to common difficulties in obtaining employment and the relatively low wage which they may be paid. On the other hand, immigrants who have been in the country for longer have greater knowledge of their rights and of standards within the host society and are therefore more aware of when discrimination takes place. Their length of stay therefore increases their expectations and demand for more equitable treatment.

The second variable that influences perceived discrimination is the connection a person has with their ethnic group, i.e. the extent to which they identify with this group. Those who identify less with their ethnicity or cultural background may be perceived by others as fitting in better into the host society and consequently face less discrimination. A weaker connection with the ethnic background may also mean less sensitivity to unfair treatment based on the cultural or ethnic connection. Hence those with a stronger attachment to their ethnic background may be more likely to both experience discrimination and perceive discriminatory practices. The causality runs in this respect both ways: the perception and experience of injustice based on ethnicity may induce a person to form stronger ties with their ethnic group (Sellers \& Shelton, 2003).

The third variable that influences the perception of discrimination is the individual's level of education. Studies done around the world have concluded that education affects the expectation of success over the life course and the awareness of wage and opportunity inequalities between people (Cardarelli et al., 2007). Immigrants with higher education are likely to be more aware of their rights. Higher educated immigrants are also said to be more likely to compare themselves with others by their level of education. They are therefore more sensitive to differential treatment when applying for the same job as similarly educated natives. If highly educated immigrants believe that their education is being discounted or 
undervalued they are more likely to report perceiving discrimination. It is also possible that migrants who are higher educated are perceived as more 'threatening' to the native born population, and therefore more likely to be targeted for discrimination.

The fourth variable that may play a role is occupation. Some occupations have higher status than others. When labour markets are segmented, and many migrants can only find employment in relatively lower status occupations, they are also more likely to perceive more discrimination.

A fifth factor influencing the perception of discrimination is the presence of income inequality. If an immigrant perceives his or her income to be lower than that of a colleague with similar education and experience, they may perceive this as discriminatory. Relatively large income inequality among the foreign born is often a sign of prejudice against certain groups of immigrants.

Statistics New Zealand (2012) found that approximately 10 per cent of New Zealanders have felt discriminated against over twelve months preceding the NZGSS survey primarily due to race, skin colour or ethnicity and most commonly either while in public or in the workplace. This survey evidence is consistent with several earlier academic studies that have uncovered discrimination against migrants in the New Zealand labour market (Wilson \& Parker, 2007). Spoonley \& Gendall (2010) argue that there is alarming evidence that New Zealand employers' attitudes towards immigrants are problematic and that they are often found to discriminate on minor attributes such as accents and surname. Recent media reports suggest that particularly foreign sounding names act as a barrier in obtaining work. Gendall et al. (2007) were surprised to find that younger people in New Zealand were less supportive and less tolerant of immigrants than people in older age groups. The same study reported that 93 per cent of New Zealanders have heard some discriminatory remarks about immigrants at some point. Most survey respondents acknowledged the existence of racism within New 
Zealand and commented that it was mostly targeted towards immigrants. There was also a sense of fear by many of the survey respondents that New Zealand's culture may be overwhelmed by those of immigrants. Gendall et al. (2007) conclude that there are signs that New Zealand society has a very fragile tolerance of non-English speaking immigrants.

Nonetheless, a study of around 2,000 randomly selected New Zealand households concluded that New Zealanders have overall positive attitudes toward immigrants and that they endorse multiculturalism to a great extent (Ward \& Masgoret, 2008). More than half of the respondents to this survey believed it was the Government's responsibility to implement the right policies and support multiculturalism. Most of the respondents believed that immigrants enrich New Zealand culture. Ward et al. (2011) considered the geographic dimension of discrimination and found that the level of perceived discrimination decreased as the density of immigrants in the community increased. Hence in contrast with some international research (see e.g. for Australia, Forrest and Dunn, 2010), Ward et al. (2011) did not find evidence that linked a higher concentration of immigrants to greater anti-immigrant sentiments. However, there were some regional differences. In Auckland, New Zealand's largest city, which is home for more than half of all immigrants, there was evidence of more negative attitudes. The study also showed that younger migrants and those with higher education experienced more frequent discrimination and felt less settled in New Zealand.

In summary, this literature review suggests that the analysis of discrimination in the workplace will need to control for a wide range of characteristics of the individuals and the local labour markets. The variables would include: years since migration, country of origin/ethnicity, education, occupation, income, location, language skills, age, gender, visa status, household characteristics and nature of the job (part-time, etc.). In the regression modelling below we account for these variables to the extent possible with the available data. 


\section{Data and Methodology}

This paper makes use of the Confidentialised Unit Record File (CURF) of the New Zealand General Social Survey (NZGSS) conducted by Statistics New Zealand in 2008. A total of 8,721 individuals were interviewed. They and their households formed a representative and random sample of the New Zealand population. The statistical analysis was conducted in STATA. The CURF includes rounded replicate weights to calculate confidence intervals for population characteristics but - since we test for significance of differences in a multivariate regression context only, in which case the benefits of sampling weights are not certain (Winship and Radbill, 1994) - STATA probability weights were not applied in the regressions (weighted regression results are available upon request and in fact very similar). The survey used in the interviews has two components: one consists of questions relevant to the whole household, and the other is a personal questionnaire. There are 14 topics covered by the survey, including housing, health, human rights, knowledge, work and skills.

Of the 8,721 individuals surveyed 4,192 (48 per cent) were people employed as wage and salary earners. More than one fifth (952 or 23 per cent) of these salary and wage earners were born overseas. Two questions in the survey were used to determine if workplace discrimination occurred: 'In the last 12 months, have you been treated unfairly or had something nasty been done to you because of the group you belong to or seem to belong to?' and 'Did this discrimination occur in the workplace?'.

The worker characteristics influencing the perception of discrimination are identified by means of probit and Heckman-probit regression methods. Probit regression was selected (vis-à-vis logit or linear probability modelling) due to both the binary nature of the dependent variable (a 'yes' or 'no' answer) and to maintain consistency with secondary estimation using the Heckman-probit regression method. Probit regressions were performed in two stages, 
firstly for the whole sample and the secondly by gender. This permitted an assessment of the extent of gender-related heterogeneity in responses.

Standard probit regressions of workplace discrimination may suffer from selection bias if, for example, potential workers who anticipate discrimination because of their limited English language proficiency decide not to seek work. To test for selection bias in our sample, we employ a variation of the standard Heckman model (see e.g. Cuddleback et al. 2004). This variation is known as the Heckman-probit regression and was first implemented by Van de Ven and Van Praag (1981) as an extension of Heckman's (1979) seminal work on dealing with selection bias. This model assumes that there is an underlying linear relationship

$$
y_{j}^{*}=\mathrm{x}_{j} \beta+u_{1 j}
$$

in which $y_{j}^{*}$ is the unobserved 'perception of discrimination', $\mathrm{x}_{j}$ is a vector of determinants with coefficients $\beta$ and $u_{1 j}$ is an error term with $u_{1} \sim N(0,1)$. We actually observe a 'yes' or 'no' answer to the NZGSS question regarding discrimination such that

$$
\text { Prob (perceived discrimination is 'yes') }=\operatorname{Prob}\left(y_{j}^{*}>0\right)
$$

However, answers to a workplace discrimination question are only available for those who are actually employed and employment is determined by the following model

$$
\text { Prob (employment is 'yes') }=\mathrm{z}_{j} \gamma+u_{2 j}>0
$$

in which $u_{2 j} \sim N(0,1), \mathrm{z}_{j}$ refers to a vector of determinants of employment and corr $\left(u_{1}, u_{2}\right)=$ $\rho$. Eq. (3) is referred to as the selection equation. For the model to be well identified, there must be several variables that explain employment but that unrelated to the perception of discrimination. The model is estimated with a maximum likelihood algorithm.

The CURF data of the NZGSS has some limitations in terms of the range and depth of respondent characteristics. Migrant groups can be in principle identified by birthplace, ethnicity, culture and language. In practice, it was only possible to classify the foreign born 
by birthplace in terms of a number of global regions; and the New Zealand born by ethnicity. Due to the limited sample size and the nature of the CURF, some of the global regions from which immigrants originate combine immigrants with different linguistic and cultural backgrounds. For example, even among those who were born in the combined region of Europe and North America, native English speakers are combined with those who speak other European languages.

Various occupation and education variables are available to determine skill levels, but when such variables are jointly included in the model this leads to multicollinearity problems. In order to proxy for human capital, years of schooling are included. There is also evidence to suggest that workplace discrimination may be particularly prevalent among semi-skilled blue collar workers (Zegers de Beijl, 2000). We identify workers with a trade certificate to capture the set of lower skilled occupations that often face higher levels of workplace discrimination.

Basic descriptive statistics of all variables used in this paper are given in Table 1. The main sample consists of 7,193 respondents aged between 16 and 64 in 2008, of whom 4,192 are salary and wage earners. 6.2 per cent of these salary and wage earners indicated that they had experienced workplace discrimination in the previous 12 months. However, workplace discrimination was higher among the foreign born as compared with the New Zealand born: 9.8 per cent versus 5.2 per cent. Among the foreign born, women were more to likely to report workplace discrimination than men: 10.3 per cent and 9.2 per cent respectively.

[Insert Table 1 here]

Due to data limitations referred to earlier, ethnicity and birthplace were combined in one classification with 10 categories that is assumed to proxy broad ethnic and cultural differences. The largest proportion of immigrants were born in Europe or North America 
(40.8 per cent) representing 9.3 per cent of all workers in the survey. Those born in Australia comprised 5.5 per cent of migrants and 1.2 per cent of total salary and wage earners. Migrants born in the Pacific Islands made up 13.1 per cent of migrants and similarly the subgroup that includes the Middle East, Latin America or Africa (MELAA) (also 13.1 per cent), followed by those that had South East Asia as their region of birth (10.1 per cent). Those born in Northern Asia accounted for 8.2 per cent while those born in other Asian regions (primarily Southern Asia) accounted for 6.1 per cent of immigrants. For those born in New Zealand, three ethnic groups were identified: Pacific Island, Maori, and European, who represented respectively 2.2 per cent, 12.5 per cent and 63.1 per cent of the total sample.

Years since migration is described by means of four discrete categories: those who migrated less than five years ago (15.6 per cent of the immigrants), those who migrated between five and nine years ago (18.9 per cent), those who migrated between ten and fourteen years ago (10.4 per cent) and those who migrated fifteen or more years ago (54.9 per cent). Migrants with less than 10 years in the New Zealand labour market made up about 8 per cent of all salary and wage earners.

Females accounted for 52.8 per cent of all salary and wage earners and 51 per cent of migrants. The foreign born were far more likely to live with a partner than the New Zealand born (70 per cent and 56.8 per cent respectively). The mean age was around 41 years for all sub samples. A slightly higher proportion of migrants than of non-migrants had dependent children. About one in five New Zealand born salary and wage earners worked part-time (less than 30 hours per week). Foreign born females were more than twice as likely as foreign born males to be employed part-time (23.6 per cent versus 10.9 per cent). Male migrants were more likely to hold a trade certificate (15.6 per cent) compared to female migrants (3.9 per cent). The emphasis on skill-based immigration in New Zealand is clear from the foreign 
born having on average nearly an extra year at school as compared with the New Zealand born (13.4 and 12.5 years respectively).

[Insert Table 2 here]

Table 2 shows the proportions that reported workplace discrimination for several worker characteristics. The overall percentage of salary and wage earners reporting workplace discrimination, 6.2 per cent, provides the benchmark. With respect to ethnic/birthplace groupings the highest incidence of discrimination was observed among those that came from the South East Asia region (14.6 per cent), followed by those born in MELAA countries (12.8 per cent). In contrast, only 4.4 per cent of New Zealand born Europeans reported discrimination. They reported 'dress or appearance', followed by age, with gender in third place as the factor that led to discrimination (Statistics New Zealand, 2012). Seven per cent of migrants from Europe or North America experienced discrimination in the workplace. Reported discrimination rates are also relatively high among NZ born Maori (10 per cent) and NZ born Pacifica (11.7 per cent).

Interestingly, the relationship between reported workplace discrimination and length of time in New Zealand is nonlinear. The rate of reported discrimination increases from 11.8 per cent in first five years to 13.6 per cent for five to nine years of residency and then decreases to eventually 6.6 per cent for migrants in New Zealand 15 or more years. Clearly, these summary statistics conflate the effects of age and duration of residence. The marginal effects of each are identified in the regressions of the next section.

As in Table 1, we see that females are more likely to report discrimination than males, and this is true for both the foreign and the New Zealand born. Those working part time and living with partners have lower than average reported discrimination rates (4.7 per cent and 
5.6 per cent respectively) while those with dependent children have higher than average rates (7 per cent).

With respect to education, reported discrimination was highest (8.6 per cent) for those who attended school between 13 to 15 years, which includes some post-secondary education; whereas among those with less education only 5.3 per cent reported discrimination. For those holding a trade certificate, the rate was slightly higher than average, 6.5 per cent. The age group with the highest proportion reporting discrimination was those aged 25 to 39 years (7.2 per cent). Among the oldest age group (aged 55 to 64) only 3.5 per cent reported discrimination.

\section{Results of Probit and Heckman-probit Regression Modelling}

Two sets of probit regression models are represented in Table 3. Standard errors have been calculated with the Huber-White-sandwich estimator to allow for unsystematic heteroscedasticity. The basic model (1) examines workplace discrimination using only region of birth and number of years since migration. The data pool the migrants with the New Zealand born, so the migration-related variables are interacted with a dummy variable which is equal to one for the foreign born only. When compared with New Zealand born Europeans, the incidence of perceived discrimination is not statistically different for those born in Australia, Europe or North America, NE Asia or South \& Other Asia. In contrast, significantly higher discrimination is found for those from the Pacific Islands, MELAA countries and particularly SE Asia. Ethnicity is also an important determinant of discrimination for NZ born Pacific Islanders and Maori.

The years since migration (YSM) variables have positive coefficients which are significant for the zero to four and five to nine categories with the five to nine YSM group showing a somewhat greater likelihood of experiencing discrimination compared to the zero 
to four YSM group. Those in New Zealand between ten and 14 years are not statistically more likely to report discrimination than those who are in New Zealand 15 years or more.

\section{[Insert Table 3 here]}

The second model, (2a), expands upon the first by including other control variables and fixed effects for New Zealand regions. These variables were selected on the basis of the literature survey and the available CURF data. However some variables which were identified as potentially holding explanatory power were dropped due to multicollinearity or unable to be included due to deficiencies in the GSS data. Having a partner, holding a trade certificate, education, and those who work in Wellington are statistically significant at least at the 10 per cent level. The presence of a partner lowers perceived discrimination. In line with previous literature, the more educated are more likely to report discrimination and the kinds of jobs that require vocational training (which are signalled by the possession of a trade certificate) are also generating relatively more reported discrimination. Perceived discrimination is lower in the capital Wellington, where the public service (which accounts for up to $30 \%$ of employment there) may be expected to adhere more strongly than employers generally to equal employment opportunities and human rights legislation.

Although the gender difference in the descriptive statistics of Tables 1 and 2 suggests higher perceived discrimination among females, this effect is not statistically significant (model 2a). The last two columns in Table 3 focus on heterogeneity by gender with respect to the impact of the various determinants of self-reported discrimination. For males, the coefficients for immigrants born in South East Asia and Pacific Islanders born in New Zealand are no longer statistically significant. Instead, we now find a large coefficient for South \& Other Asia (in New Zealand these migrants were predominantly sourced from India) 
which is significant at the five per cent level. Male migrants who have been in New Zealand less than five years are more likely to perceive discrimination, but the coefficient for five to nine years is no longer significant. The coefficients of 'Partner' and 'Live in Wellington' are also no longer significant.

The probit regression for females yields quite different results. In regression (2c) being born in South East Asia (migrants predominantly from the Philippines and Malaysia) yields significantly higher reported discrimination. The same is true for New Zealand born women of Pacific Island ethnicity. The higher self-reported discrimination by NZ Maori is the only ethnicity factor that is common for men and women.

The effect of being in New Zealand less than five years is not significant for women, but for female migrants five to nine years in the country, the incidence of reporting discrimination is notably higher. This could be related to female migrants entering later into the host country labour market than men. This is confirmed by the participation equations of Table 4. The trade certification variable is not significant for females, who are less likely to be employed in blue collar occupations. Additional years of schooling are significantly related to an increase in reporting of feelings of discrimination amongst women. Having a partner reduces the likelihood of a woman reporting discrimination. Finally, the nonlinear age effect is statistically significant for women and suggests the highest reporting rates at age 40 .

[Insert Table 4 here]

Given the gender differences in the probit regressions shown in Table 3, the Heckman-probit regressions in Table 4 are also gender specific. These regressions take account of the fact that perceived workplace discrimination can only be observed among those who are in employment. There may be unobserved factors that are not explicitly taken into account in 
the model (such as English language proficiency) that affect both the likelihood of employment as well as the perception of discrimination, i.e. there is correlation between the error terms in the participation and discrimination models (see e.g. Van de Ven \& Van Praag, 1981). When we ignore the correlation between these factors that affect employment as well as discrimination, the coefficients in the regressions of Table 3 have a positive bias if such unmeasured factors lower participation but increase reported discrimination. The ‘truncation' of participation then erroneously leads us to attribute too much impact to observed factors that are positively associated with reported discrimination, whereas in fact some of that impact is due to the unobserved variables. For factors that increase participation and lower discrimination (e.g. being 'good looking' or having 'good social skills'), the bias in the regressions of Table 3 is expected to be negative. In practice, there may be a mixture of unobserved influences and the direction of the bias is then not theoretically determinate.

However, the selection cannot be identified unless there are exogenous factors that influence participation but may be assumed to be unrelated to workplace discrimination. We selected three such factors available from the CURF data: the presence of children (which measures the opportunity cost of time devoted to work), the number of bedrooms in the respondent's dwelling (a wealth effect or, more likely for salary and wage earners, the impact of the size of household mortgage debt) and the accessibility of public facilities, such as shops, schools, libraries and medical services.

These ideas are confirmed by the regressions in Table 4. Of the sample of 3,015 males, 1,959 (or 65 per cent) are employed as salary and wage earners and therefore answered the question about workplace discrimination. The Heckman probit model is estimated with the maximum likelihood method in which the correlation parameter between the discrimination and selection equations is not directly estimated but instead given by the inverse hyperbolic tangent function of the correlation coefficient $\rho$. This atanh $(\rho)$ parameter 
is 2.455 for male employment and statistically significant at the 1 per cent level (also confirmed by the $\chi^{2}(1)$ test). The implied correlation between unobserved determinants of employment and discrimination is quite high, 0.807. For women the selection effect is not statistically significant and, consequently, the results of column (2c) of table 3 remain valid (they are in fact very similar to those of column (4a) in Table 4).

Turning to the regressions for men, the likelihood of salary and wage employment is significantly less for those from MELAA countries, North East Asia, New Zealand born Pacific Islanders and Maori. Consequently, compared with regression (2b) in Table 3, the coefficients are now less positive for all birthplace/ethnic groups and in fact no longer statistically significant for those born in the Pacific Islands and MELAA countries.

For women, discrimination remains more reported among those from South East Asia, but those from North East Asia and South \& Other Asia have lower employment rates. The gender differences with respect to NZ born Pacific Islanders and Maori are particularly interesting. For both genders, these ethnic groups have lower participation. However for women this coincides with higher self-reported discrimination among NZ born Pacific Islanders (with a coefficient that is even greater than in regression (2c) of Table 3), whereas for men this is the case among Maori.

The years since migration dummy does not affect the salary and wage employment rate of males, but being less than five years in the country remains a significant predictor of greater self-reported discrimination. For women, having been in New Zealand less than five years lowers the probability of employment, as noted previously. Then, again as in Table 3, column (2c), being in New Zealand five to nine years leads to higher reported discrimination among migrant women.

Having a partner significantly increases the employment propensity of men, while having children does the opposite. However, the presence of children negatively affects 
female employment much more than male employment, as can be expected. Women with a partner perceive less discrimination.

The effect of the size of the house (as measured by the number of bedrooms) on participation is positive (consistent with a mortgage effect) and similar for both genders. Accessibility of transport, which presumably also facilitates commuting, increases the employment rate of men and women. All three of the exogenous factors that identify the employment equation are statistically significant at the 1 per cent level in the regressions for both males and females.

The use of the Heckman-probit models shows that the age effect on discrimination is now just as significant for men as it is for women and the coefficients are similar. The peak age of self-reported workplace discrimination is 38 for men and 43 for women. Years of schooling positively affect participation of men and women. The Heckman probit regressions have therefore somewhat larger coefficients for schooling in explaining discrimination, but the effect is only statistically significant for women. The coefficient of holding a trade certificate is also positively associated with discrimination for men, but it has no statistically significant impact on male participation.

Interestingly, salary and wage employment is lower in Auckland, all else being equal (possibly associated with higher rates of unemployment in 2008 and higher rates of selfemployment) for both genders. Perceived discrimination is lower in the Wellington region, but only among women.

\section{Conclusions}

This paper focussed explicitly on differences between the New Zealand born and the foreign born in the incidence of perceived discrimination in New Zealand workplaces. Overall, self-reported workplace discrimination is rather uncommon in the New Zealand 
labour market, with just over six per cent of workers in the NZGSS 2008 survey stating that they 'in the last 12 months had been treated unfairly or had something nasty done to them because of the group they belong to or seem to belong to?'. We adopted multivariate probit modelling to disentangle a range of factors that have been suggested in the literature to influence discrimination and, importantly, we also test for selection effects that may make groups that are discriminated against less likely to be in employment. We found that there are important differences between men and women with respect to workplace discrimination and we proceeded to estimate models for the two genders separately.

We found indeed that those who migrated from Asia are more likely to be exposed to workplace discrimination than other New Zealand workers. However, Asia turns out to be too broad a classifier: for men, only those born in South \& Other Asia (predominantly from India) experience more discrimination all else being equal, whereas for women this applies to those from Southeast Asia (predominantly from the Philippines and Malaysia). For men from North East Asia (predominantly from China) the discrimination may be reflected in lower employment rates. Generally, for migrants the situation does improve with time lived in New Zealand.

There are no major differences between New Zealand regions, but those working in the capital Wellington appear to perceive less discrimination. Additional robust results are: firstly, that having a partner lowers reported discrimination of women; secondly, the age effect is non-linear with highest self-reporting at mid-career (around age 40); and, thirdly, reporting discrimination is positively related to schooling for women and being employed in trades for men.

There is much scope for further research in this area, even accepting the limitations of the NZGSS CURFs. Future work that combines the 2008 and 2010 CURFs will allow for a greater sample size and a consideration of recent trends. Research on migrant/non-migrant 
differences in causes of discrimination at work beyond ethnicity, such as appearance, age, sex, occupation and religious beliefs would be important. There is also information on frequency of experiencing discriminatory remarks or acts. Analysis of this information was beyond the scope of the present paper but can be investigated in future research. Moreover, while the present paper looked through the selection model at the relationship between discrimination and being employed as a salary or wage earner, the impact of discrimination on employment opportunities, overall life satisfaction and health could also be investigated. It would also be fruitful to disentangle the relationship between discrimination in the workplace and at other locations with social connectedness and a sense of identity. Finally, the ethnic effects identified in this paper may be strongly linked with language ability since language is a very important determinant of labour market success among migrants (e.g. Chiswick and Miller, 1999). However, the data were inadequate to disentangle cultural effects from language effects. Future research could focus on the extent to which fluency in the English language reduces discrimination and, hence, the extent to which post-settlement language training could contribute to reducing the incidence of discrimination in the workplace.

\section{References}

Banerjee, R. (2008), 'An Examination of Factors Affecting Perception of Workplace Discrimination', Journal of Labor Research, 29, 380-401.

Cardarelli, R., Cardarelli, K.M. and Chiapa, A.L. (2007), 'The Modifying Effects of Education and Income on Hispanics Reporting Perceived Discrimination', Hispanic Journal of Behavioral Sciences, 29(3), 401-407.

Castles, S. (2000), Etnicity and Globalisation, Sage Publications, London. 
Chiswick, B.R. and Miller, P.W. (1999), ‘Language Skills and Earning among Legalized Aliens', Journal of Population Economics, 12, 63-89.

Cuddleback, G., Wilson, E., Orme, J.G. and Combs-Ornme, T. (2004), ‘Detecting and Statistically Correcting Sample Selection Bias’, Journal of Social Service Research, 30(3), 19-33.

Department of Labour (2009), Migration Trends and Outlook 2008-2009, Department of Labour, Wellington.

EEO Trust (2005), Versatile Workplace: Business Success, Equal Employment Opportunities Trust of New Zealand, Auckland.

EEO Trust (2008), Diversity and Equality; Evidence of Positive Business Outcomes and How to Achieve Them, Equal Employment Opportunities Trust of New Zealand, Auckland.

Forrest, J. and Dunn, K. (2010), 'Attitudes to Multicultural Values in Diverse Paces in Australia’s Immigrant Cities, Sydney and Melbourne’, Space and Polity, 14(1), 81102.

Gendall, P., Spoonley, P., and Trlin, A. (2007), The Attitudes of New Zealanders to Immigrants and Immigration: 2003 and 2006 Compared. Massey University: Palmerston North.

Girling, A. N., Liu, J. H., and Ward, C. (2010), Confident, Equal and Proud? A Discussion Paper on the Barriers Asians Face to Equality in New Zealand, Human Rights Commision, Wellington.

Groeneveld, S. and Verbeek, S. (2012), 'Diversity Policies in Public and Private Sector Organizations: An Empirical Comparison of Incidence and Effectiveness', Review of Public Personnel Administration, 32(4), 353-381. 
Heckman, J. (1979), 'Sample Selection Bias as a Specification Error', Econometrica, 47, 153-162.

Heywood, J.S. (1989) 'Wage Discrimination by Race and Gender in the Public and Private Sectors', Economics Letters, 29, 99-102.

Hodgson, R. and Poot, J. (2010), New Zealand Research on the Economic Impacts of Immigration 2005-2010: Synthesis and Research Agenda. Department of Labour, Wellington.

Kaiser, C.R. and Major, B. (2006), 'A Social Psychological Perspective on Perceiving and Reporting Discrimination', Law \& Social Inquiry, 31(4), 801-830.

Lang, K. and Lehmann, J.-Y.K. (2012), 'Racial Discrimination in the Labor Market: Theory and Empirics’, Journal of Economic Literature, 50(4), 959-1006.

Lewis, D., French, E., and Phetmany, T. (2000), 'Cross-Cultural Diversity, Leadership and Workplace Relations in Australia’, Asia Pacific Business Review, 7(1), 105-124.

North, N.H. (2007), 'Employers' Attitudes and Practices on the Hiring of Immigrants', in: P.S. Morrison (ed.) Labour, Employment and Work in New Zealand 2006: Proceedings of the Twelfth Conference, Victoria University of Wellington, Wellington.

Oreopoulos, P. (2011), 'Why do Skilled Immigrants Struggle in the Labor Market? A Field Experiment with Thirteen Thousand Resumes', American Economic Journal: Economic Policy, 3(4), 148-171.

Page, S. (2007), The Difference: How the Power of Diversity Creates Better Groups, Firms, Schools, and Societies, Princeton University Press, Princeton. 
Pager, D. and Western, B. (2012), 'Identifying Discrimination at Work: The Use of Field Experiments’, Journal of Social Issues, 68(2), 221-237.

Poot, J. and Stillman, S. (2010), 'The Importance of Heterogeneity when Examining Immigrant Education-Occupation Mismatch: Evidence from New Zealand', Research Report Number 3, Integration of Immigrants Programme, Massey University and Waikato University.

Sellers, R., and Shelton, J.N. (2003), 'Role of Racial Identity in Perceived Racial Discrimination’ Journal of Personality and Social Psychology, 85(5), 1079-1092.

Spoonley, P. and Gendall, P. (2010), 'Welcome to our World: Attitudes to Immigrants and Immigration', in A. Trlin, P. Spoonley and R. Bedford (eds), New Zealand and International Migration: A Digest and Bibliography, No. 5, Massey University, Palmerston North, pp. 136-158.

Spoonley, P. and Bedford, D. (2012), Welcome to Our World? Immigration and the Reshaping of New Zealand, Dunmore Publishing Ltd.,Wellington.

Statistics New Zealand (2012), Working Together: Racial Discrimination in New Zealand, Statistics New Zealand, Wellington.

Trenerry, B., Franklin, H., and Paradies, Y. (2012), Preventing Race-Based Discrimination and Supporting Cultural Diversity in the Workplace - An Evidence Review: Full Report, Victorian Health Promotion Foundation, Melbourne.

Van de Ven, W.P.M.M. and Van Praag, B.M.S. (1981), The Demand for Deductibles in Private Health Insurance: a Probit Model with Sample Selection, Journal of Econometrics, 17, 229-252. 
Ward, C. and Masgoret, A.M. (2008), 'Attitudes toward Immigrants, Immigration, and Multiculturalism in New Zealand: A Social Psychological Analysis', International Migration Review, 42(1), 227-248.

Ward, C., Masgoret, A.M., and Vauclair, M. (2011), 'Attitudes towards Immigrants and Immigrant Experiences: Predictive Models Based on Regional Characteristics', Department of Labour, Wellington.

Watson, B., Spoonley, P. and Fitzgerald, E. (2009), 'Managing Diversity: A Twenty-First Century Agenda’, New Zealand Journal of Employment Relations, 34(2), 61-76.

Watts, N. and Trlin, A. (2000), 'Diversity as a Productive Resource: Employment of Immigrants from Non-English Speaking Backgrounds in New Zealand', Social Policy Journal of New Zealand, 15, 87-101.

Wilson, M.G. and Parker, P. (2007), 'The Gap between Immigration and Employment: A Policy-Capturing Analysis of Ethnicity-Driven Selection Bias’, New Zealand Journal of Employment Relations, 32(1), 28-44.

Winship, C. and Radbill, L. (1994) 'Sampling Weights and Regression Analysis’, Sociological Methods \& Research, 23, 230-257.

Zegers de Beijl, R. (ed.) (2000), Documenting Discrimination against Migrant Workers: A Comparative Study of Four European Countries, International Labour Office, Geneva. 
Table 1: Summary statistics of variables used in the multivariate analysis

\begin{tabular}{|c|c|c|c|c|c|}
\hline \multirow[b]{2}{*}{ variable } & \multirow[b]{2}{*}{ Pooled } & \multirow[b]{2}{*}{$\begin{array}{c}\text { NZ } \\
\text { Born }\end{array}$} & \multicolumn{3}{|c|}{ Foreign born } \\
\hline & & & All & Female & Male \\
\hline Workplace discrimination & $6.2 \%$ & $5.2 \%$ & $9.8 \%$ & $10.3 \%$ & $9.2 \%$ \\
\hline Born in Australia & $1.2 \%$ & na & $5.5 \%$ & $5.6 \%$ & $5.4 \%$ \\
\hline Born in Pacific Islands & $3.0 \%$ & na & $13.1 \%$ & $9.7 \%$ & $16.7 \%$ \\
\hline $\begin{array}{l}\text { Born in Europe or North } \\
\text { America }\end{array}$ & $9.3 \%$ & na & $40.8 \%$ & $40.4 \%$ & $41.1 \%$ \\
\hline $\begin{array}{l}\text { Born in Middle East, Latin } \\
\text { America or Africa (MELAA) }\end{array}$ & $3.0 \%$ & na & $13.1 \%$ & $14.6 \%$ & $11.6 \%$ \\
\hline Born in SE Asia & $2.3 \%$ & na & $10.1 \%$ & $12.8 \%$ & $7.3 \%$ \\
\hline Born in NE Asia & $1.9 \%$ & na & $8.2 \%$ & $9.1 \%$ & $7.3 \%$ \\
\hline Born in other Asian regions & $1.4 \%$ & na & $6.1 \%$ & $5.6 \%$ & $6.6 \%$ \\
\hline $\begin{array}{l}\text { Born in NZ and of Pacific } \\
\text { ethnicity }\end{array}$ & $2.2 \%$ & $2.9 \%$ & na & na & na \\
\hline $\begin{array}{l}\text { Born in NZ and of Maori } \\
\text { ethnicity }\end{array}$ & $12.5 \%$ & $16.0 \%$ & na & na & na \\
\hline $\begin{array}{l}\text { Born in NZ and of European } \\
\text { Ethnicity* }\end{array}$ & $63.1 \%$ & $81.6 \%$ & na & na & na \\
\hline 0 to 4 Years since migration & $3.6 \%$ & na & $15.6 \%$ & $16.2 \%$ & $15.5 \%$ \\
\hline 5 to 9 Years since migration & $4.3 \%$ & na & $18.9 \%$ & $18.3 \%$ & $19.7 \%$ \\
\hline $\begin{array}{l}10 \text { to } 14 \text { Years since } \\
\text { migration }\end{array}$ & $2.4 \%$ & na & $10.4 \%$ & $9.9 \%$ & $11.0 \%$ \\
\hline $15+$ Years since migration* & $12.6 \%$ & na & $54.9 \%$ & $55.6 \%$ & $53.9 \%$ \\
\hline Female & $52.8 \%$ & $53.4 \%$ & $51.0 \%$ & na & na \\
\hline Male* & $47.2 \%$ & $46.6 \%$ & $49.0 \%$ & na & na \\
\hline Living with partner & $59.8 \%$ & $56.8 \%$ & $70.0 \%$ & $67.4 \%$ & $72.6 \%$ \\
\hline Age (mean) & 40.8 & 40.7 & 41.6 & 41.4 & 41.9 \\
\hline $\begin{array}{l}\text { Living with dependent } \\
\text { children }\end{array}$ & $40.8 \%$ & $40.3 \%$ & $42.4 \%$ & $39.8 \%$ & $45.2 \%$ \\
\hline Employed part-time & $19.3 \%$ & $20.0 \%$ & $16.8 \%$ & $23.6 \%$ & $10.9 \%$ \\
\hline Holds a trade certificate & $11.5 \%$ & $12.0 \%$ & $9.7 \%$ & $3.9 \%$ & $15.6 \%$ \\
\hline Years of schooling (mean) & 12.7 & 12.5 & 13.4 & 13.5 & 13.3 \\
\hline Observations & 4,192 & 3,240 & 952 & 485 & 467 \\
\hline
\end{tabular}

Note: na: not applicable, * denotes reference category used in estimations. 
Table 2: Incidence of perceived discrimination by group $(n=4,192)$

Group

$\%$ reporting workplace discrimination

Pooled sample

$6.2 \%$

Born in Australia

$9.6 \%$

Born in Pacific Islands

$9.6 \%$

Born in Europe or Nth America

$7.0 \%$

Born in MELAA

$12.8 \%$

Born in SE Asia

$14.6 \%$

Born in NE Asia

$11.5 \%$

Born in South Asia and Other Asia

$12.1 \%$

NZ born Pacific

$11.7 \%$

NZ born Maori

$10.0 \%$

NZ born European

$4.4 \%$

Migrated less than 5 years ago

$11.8 \%$

Migrated 5 to 9 years ago

$13.6 \%$

Migrated 10 to 14 years ago

$10.8 \%$

Migrated 15 or more years ago

$6.6 \%$

Female

$6.6 \%$

Male

$5.8 \%$

Working part-time

$4.7 \%$

Live with partner

$5.6 \%$

Have dependent children

$7.0 \%$

Attended less than 13 years of schooling

Attended 13 to 15 years of schooling

$8.6 \%$

Attended 16 or more years of schooling

$5.9 \%$

Holds a trade certificate

$6.5 \%$

Aged between 16 and 24

$5.8 \%$

Aged between 25 and 39

$7.2 \%$

Aged between 40 and 54

$6.7 \%$

Aged between 55 and 64

$3.5 \%$ 
Table 3: Probit regression model of workplace discrimination for all employed

\begin{tabular}{|c|c|c|c|c|}
\hline VARIABLES & $\begin{array}{c}(1) \\
\text { Basic } \\
(n=4,192)\end{array}$ & $\begin{array}{l}(2 \mathrm{a}) \\
\text { Full controls } \\
(n=4,192)\end{array}$ & $\begin{array}{c}(2 b) \\
\text { Male only } \\
(n=1,977)\end{array}$ & $\begin{array}{c}(2 \mathrm{c}) \\
\text { Female only } \\
(n=2,215)\end{array}$ \\
\hline Born in Australia & $\begin{array}{l}0.249 \\
(0.247)\end{array}$ & $\begin{array}{c}0.219 \\
(0.250)\end{array}$ & $\begin{array}{c}0.196 \\
(0.348)\end{array}$ & $\begin{array}{c}0.312 \\
(0.339)\end{array}$ \\
\hline Born in Pacific Is & $\begin{array}{l}0.287 * \\
(0.165)\end{array}$ & $\begin{array}{c}0.397^{* *} \\
(0.173)\end{array}$ & $\begin{array}{l}0.413^{*} \\
(0.241)\end{array}$ & $\begin{array}{c}0.374 \\
(0.253)\end{array}$ \\
\hline Born in Europe or Nth Ame. & $\begin{array}{l}0.091 \\
(0.132)\end{array}$ & $\begin{array}{c}0.097 \\
(0.136)\end{array}$ & $\begin{array}{l}-0.017 \\
(0.214)\end{array}$ & $\begin{array}{c}0.176 \\
(0.178)\end{array}$ \\
\hline $\begin{array}{l}\text { Born in Mid East, Latin } \\
\text { America or Africa } \\
\text { (MELAA) }\end{array}$ & $\begin{array}{l}0.338 * \\
(0.187)\end{array}$ & $\begin{array}{l}0.336^{*} \\
(0.185)\end{array}$ & $\begin{array}{c}0.556^{* *} \\
(0.263)\end{array}$ & $\begin{array}{c}0.156 \\
(0.272)\end{array}$ \\
\hline Born in SE Asia & $\begin{array}{l}0.443 * * \\
(0.175)\end{array}$ & $\begin{array}{c}0.465^{* *} \\
(0.181)\end{array}$ & $\begin{array}{c}0.233 \\
(0.337)\end{array}$ & $\begin{array}{c}0.567 * * \\
(0.225)\end{array}$ \\
\hline Born in NE Asia & $\begin{array}{l}0.259 \\
(0.209)\end{array}$ & $\begin{array}{c}0.263 \\
(0.215)\end{array}$ & $\begin{array}{c}0.361 \\
(0.332)\end{array}$ & $\begin{array}{c}0.159 \\
(0.286)\end{array}$ \\
\hline Born in South \& Other Asia & $\begin{array}{l}0.260 \\
(0.239)\end{array}$ & $\begin{array}{c}0.284 \\
(0.246)\end{array}$ & $\begin{array}{c}0.668 * * \\
(0.307)\end{array}$ & $\begin{array}{l}-0.549 \\
(0.479)\end{array}$ \\
\hline NZ born Pacific Is & $\begin{array}{l}0.464 * * * \\
(0.177)\end{array}$ & $\begin{array}{c}0.488 * * * \\
(0.178)\end{array}$ & $\begin{array}{c}0.173 \\
(0.356)\end{array}$ & $\begin{array}{c}0.633 * * * \\
(0.214)\end{array}$ \\
\hline NZ born Maori & $\begin{array}{l}0.429 * * * \\
(0.086)\end{array}$ & $\begin{array}{c}0.452 * * * \\
(0.089)\end{array}$ & $\begin{array}{c}0.571 * * * \\
(0.131)\end{array}$ & $\begin{array}{c}0.344 * * * \\
(0.123)\end{array}$ \\
\hline 0 to $4 \mathrm{YSM}$ & $\begin{array}{l}0.318^{* *} \\
(0.152)\end{array}$ & $\begin{array}{l}0.295^{*} \\
(0.155)\end{array}$ & $\begin{array}{c}0.445^{* *} \\
(0.222)\end{array}$ & $\begin{array}{c}0.108 \\
(0.229)\end{array}$ \\
\hline 5 to 9 YSM & $\begin{array}{l}0.392 * * * \\
(0.148)\end{array}$ & $\begin{array}{c}0.378 * * \\
(0.151)\end{array}$ & $\begin{array}{c}0.259 \\
(0.238)\end{array}$ & $\begin{array}{c}0.551 * * * \\
(0.203)\end{array}$ \\
\hline 10 to $14 \mathrm{YSM}$ & $\begin{array}{l}0.246 \\
(0.182)\end{array}$ & $\begin{array}{c}0.246 \\
(0.184)\end{array}$ & $\begin{array}{c}0.369 \\
(0.250)\end{array}$ & $\begin{array}{c}0.078 \\
(0.267)\end{array}$ \\
\hline Female & & $\begin{array}{c}0.069 \\
(0.064)\end{array}$ & & \\
\hline Partner & & $\begin{array}{c}-0.180 * * * \\
(0.067)\end{array}$ & $\begin{array}{c}-0.138 \\
(0.104)\end{array}$ & $\begin{array}{c}-0.201 * * \\
(0.089)\end{array}$ \\
\hline Age & & $\begin{array}{c}0.023 \\
(0.016)\end{array}$ & $\begin{array}{l}-0.005 \\
(0.022)\end{array}$ & $\begin{array}{c}0.046 * * \\
(0.023)\end{array}$ \\
\hline $\operatorname{Age}^{2} / 100$ & & $\begin{array}{c}-0.029 \\
(0.019)\end{array}$ & $\begin{array}{c}0.004 \\
(0.027)\end{array}$ & $\begin{array}{c}-0.057^{* *} \\
(0.028)\end{array}$ \\
\hline Years of schooling & & $\begin{array}{c}0.035 * * \\
(0.015)\end{array}$ & $\begin{array}{c}0.019 \\
(0.023)\end{array}$ & $\begin{array}{c}0.047 * * \\
(0.019)\end{array}$ \\
\hline Hold trade certificate & & $\begin{array}{c}0.174^{*} \\
(0.103)\end{array}$ & $\begin{array}{c}0.283^{* *} \\
(0.121)\end{array}$ & $\begin{array}{l}-0.285 \\
(0.269)\end{array}$ \\
\hline Live in Auckland & & $\begin{array}{l}-0.068 \\
(0.086)\end{array}$ & $\begin{array}{l}-0.073 \\
(0.132)\end{array}$ & $\begin{array}{l}-0.061 \\
(0.114)\end{array}$ \\
\hline Live in Wellington & & $\begin{array}{l}-0.154 * \\
(0.093)\end{array}$ & $\begin{array}{l}-0.140 \\
(0.148)\end{array}$ & $\begin{array}{c}-0.143 \\
(0.121)\end{array}$ \\
\hline Live in Canterbury & & $\begin{array}{c}0.079 \\
(0.090)\end{array}$ & $\begin{array}{c}0.074 \\
(0.131)\end{array}$ & $\begin{array}{c}0.065 \\
(0.127)\end{array}$ \\
\hline Constant & $\begin{array}{l}-1.735^{* * *} \\
(0.043)\end{array}$ & $\begin{array}{c}-2.534^{* * *} \\
(0.335)\end{array}$ & $\begin{array}{c}-1.892 * * * \\
(0.462)\end{array}$ & $\begin{array}{c}-3.025^{* * *} \\
(0.494)\end{array}$ \\
\hline
\end{tabular}


Robust standard errors in parentheses, ${ }^{* *} \mathrm{p}<0.01,{ }^{* *} \mathrm{p}<0.05,{ }^{*} \mathrm{p}<0.1$, 
Table 4: Heckman-probit regression model of workplace discrimination by gender VARIABLES

(3a) Male (3b) Male disc.

Born in Australia

Born in Pacific Is

Born in UK or Nth America

Born in Mid East, Latin

America or Africa

(MELAA)

Born in SE Asia

Born in NE Asia

Born in South \& Other Asia

NZ born Pacific Is

NZ born Maori

0 to 4 YSM

5 to 9 YSM

10 to $14 \mathrm{YSM}$

Partner

Age

Age $^{2} / 100$

Years of schooling

Hold trade certificate

Live in Auckland

Live in Wellington

Live in Cantabury

Children

Bedrooms emp. $(n=1,959) \quad(n=3,015)$ -0.058
$(0.439)$

$$
0.321
$$

(0.240)

$-0.053$

$(0.219)$

0.380

(0.260)

0.215

(0.331)

0.273

(0.318)

$0.626 * *$

(0.303)

$-0.190$

(0.411)

$0.427 * * *$

(0.131)

$0.498 * *$

(0.218)

0.294

(0.232)

0.268

(0.263)

$-0.051$

(0.104)

$0.062 * * *$

(0.022)

$-0.081^{* * *}$

(0.027)

0.027

(0.023)

$0.319 * * *$

(0.120)

$-0.131$

(0.131)

$-0.188$

(0.153)

0.077

(0.129)

-0.083
$(0.314)$

(0.314)

0.122

(0.175)

$-0.049$

(0.113)

$-0.601 * * *$

(0.196)

$-0.116$

(0.285)

$-1.007 * * *$

(0.231)

$-0.470$

(0.306)

$-0.664 * * *$

(0.191)

$-0.360 * * *$

(0.093)

0.310

(0.209)

$-0.052$

(0.178)

$-0.180$

(0.184)

$0.650 * * *$

(0.079)

$0.213^{* * *}$

(0.011)

$-0.287 * * *$

(0.013)

$0.093^{* * *}$

(0.017)

0.113

(0.085)

$-0.329 * * *$

(0.084)

$-0.035$

(0.098)

$-0.135$

(0.090)

$-0.300 * * *$

(0.081)

$0.123^{* * *}$

(0.038) (4a) Female disc.

(4b) Female emp.

$n=4,178)$

$-0.148$

(0.239)

$-0.082$

(0.166)

$-0.065$

(0.092)

(0.190)

0.028

(0.293)

(0.153)

$0.589 * * *$

0.182

(0.226)

0.124

(0.176)

(0.296)

$-0.635 * * *$

(0.170)

$-0.474 * *$

$-0.529$

(0.209)

(0.482)

-0.271 *

(0.219)

(0.147)

0.217

(0.136)

$-0.206 * * *$

(0.070)

0.201

$-0.256 *$

(0.234)

$0.515 * *$

(0.216)

0.151

(0.271)

$-0.189 * *$

(0.092)

$0.073 * * *$

(0.027)

$-0.087 * * *$

(0.033)

$0.063 * * *$

(0.021)

$-0.192$

(0.267)

$-0.111$

(0.119)

$-0.248 *$

(0.130)

0.036

(0.130)

(0.140)

$-0.182$

(0.136)

$-0.133$

(0.174)

0.044

(0.051)

$0.189 * * *$

(0.009)

$-0.253^{* * *}$

(0.010)

$0.091^{* * *}$

(0.012)

0.162

(0.123)

$-0.211^{* * *}$

(0.064)

0.064

(0.070)

$-0.081$

(0.072)

$-0.837 * * *$

(0.060)

$0.103^{* * *}$

(0.029) 


\begin{tabular}{|c|c|c|c|c|}
\hline Transport & & $\begin{array}{c}0.409 * * * \\
(0.114)\end{array}$ & & $\begin{array}{c}0.261^{* * *} \\
(0.086)\end{array}$ \\
\hline Constant & $\begin{array}{c}-3.324 * * * \\
(0.461)\end{array}$ & $\begin{array}{c}-4.329 * * * \\
(0.331)\end{array}$ & $\begin{array}{c}-3.912 * * * \\
(0.632)\end{array}$ & $\begin{array}{c}-3.730 * * * \\
(0.246)\end{array}$ \\
\hline Atanh $(\rho)$ & & $\begin{array}{l}2.455^{* * * *} \\
(0.804)\end{array}$ & & $\begin{array}{l}0.262 \\
(0.249)\end{array}$ \\
\hline Implied $\rho$ & & 0.807 & & 0.430 \\
\hline$\chi^{2}(1)$ & & $7.89 * * *$ & & 0.83 \\
\hline
\end{tabular}

